\title{
Pengaruh Opini Going Concern, Pergantian Manajemen Dan Ekspansi Internal Terhadap Auditor Switching Secara Voluntary
}

\author{
Fitrilya Luli Karina, Masiyah Kholmi dan Gina Harventy \\ Program Studi Akuntansi Fakultas Ekonomi Dan Bisnis \\ Universitas Muhammadiyah Malang \\ Jl. Raya Tlogomas No. 246 Malang 65144
}

\begin{abstract}
The purpose of this study is to examine the influence of voluntary opinion concerns and auditing switching on manufacturing companies listed on the BEI 2010-2013. This type of research is associative. Sampling technique using purposive sampling. Types of data used are secondary data in the form of financial statements of the company and data collection techniques is documentation. the results of this study can be concluded that partially (statistical test $T$ ) change management variables, ROA and EPS growth rates do not affect the switching auditor, while for the variable opinion of going concern and sales growth rate affect switching auditors at manufacturing companies listed on the Stock Exchange that year. In addition, $F$ test results explain that together the variable of going concern opinion, change of management, and internal expansion with proxy of growth rate ROA (Return On Assets), EPS (Earning Per Share), sales influence to auditor switching.
\end{abstract}

Keywords: going concern opinion, change of management, internal expansion, switching auditor.

\section{PENDAHULUAN}

Perkembangan dunia bisnis yang sangat pesat membuat bisnis-bisnis dari sektor manufaktur banyak diminati oleh para investor, karena sektor manufaktur memiliki andil cukup besar dalam mengubah tatanan perokonomian dunia. Kendali dari aktivitas perekonomian dunia sebagian besar juga berasal dari aktivitas perusahaan manufaktur. Keadaan tersebut yang memunculkan sebuah persaingan sangat ketat antar perusahaan.

Persaingan bisnis tidak lain hanya untuk mempertahankan nilai perusahaan di mata kreditur maupun pemegang saham. Seperti halnya kasus pada PT. Kimia Farma (PT. KAEF) yang mengganti auditornya karena diduga tidak dapat memenuhi keinginan pihak manajemennya, hal tersebut telah mencerminkan bahwa adanya perbedaan kepentingan dari masing-masing pihak yang berkepentingan.

Perbedaan kepentingan ini dipicu oleh perbedaan dalam menggunakan laporan keuangan, baik dari pihak manajemen, pemegang saham maupun pihak ketiga akan berlomba-lomba dalam mendapatkan informasi yang dibutuhkannya. Disinilah seorang mediator atau disebut akuntan publik sangat dibutuhkan untuk menilai kredibilitas dari laporan keuangan. Akuntan publik merupakan sebuah profesi yang memiliki tugas untuk memeriksa dan menilai apakah laporan keuangan telah disajikan secara wajar sesuai prinsip akuntansi yang berlaku umum (Halim, 2001:13).

Meningkatnya kebutuhan jasa audit berpengaruh terhadap perkembangan profesi akuntan publik di Indonesia. Hal ini menciptakan banyak alternatif pilihan bagi perusahaan untuk memilih atau berpindah dari satu KAP ke KAP lainnya, apabila auditor yang melakukan audit atas laporan keuangan tidak dapat meme-

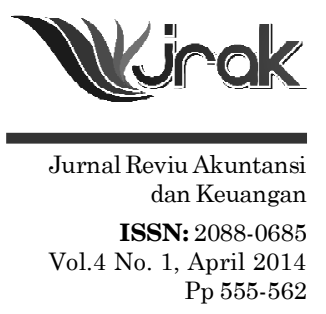




\section{Pengaruh Opini Going Concern...}

nuhi keinginan perusahaan. Namun dalam melakukan pergantian KAP, perusahaan harus tetap berlandaskan pada peraturan yang berlaku.

Keputusan Menteri Keuangan Nomor 423/KMK.06/2002 yang kemudian diubah dengan Keputusan Menteri Keuangan Nomor 359/KMK.06/2003 pasal 2 tentang "Jasa Akuntan Publik" bahwa perusahaan diwajibkan untuk mengganti Kantor Akuntan Publik (KAP) yang telah mendapat penugasan mengaudit selama lima tahun berturut- turut. Peraturan tersebut kemudian diperbarui dengan Peraturan Menteri Keuangan Nomor 17/PMK.01/2008 pasal 3 tentang "Jasa Akuntan Publik", dengan kewajiban mengganti KAP setelah melaksanakan audit selama enam tahun berturut- turut.

Peraturan rotasi melalui pergantian auditor atau sering disebut auditor switching adalah keputusan penting dalam perusahaan dan harus dipertimbangkan secara bijak mengenai auditor mana yang akan dipilih untuk bermitra kerja dengannya. Auditor switching secara mandatory memang sudah menjadi kewajiban setiap perusahaan, namun sering dipertanyakan jika suatu perusahaan melakukan auditor switching secara voluntary. Voluntary merupakan sifat sukarela dari perusahaan untuk mengganti auditornya dan dilakukan diluar peraturan dari pemerintah, yaitu kurang dari jangka waktu 6 tahun seperti yang ditetapkan (Astrini dan Muid, 2013). Kemungkinan- kemungkinan tertentu dapat menjadi sebab akibat perusahaan melakukan auditor switching secara voluntary dan memiliki implikasi terhadap kredibilitas nilai laporan keuangan.

Auditor switching secara voluntary oleh perusahaan dapat terjadi ketika lingkungan perusahaan berubah, adanya keinginan untuk memperbaiki reputasi perusahaan, dan menginginkan auditor yang lebih kompetitif lagi sesuai dengan keadaan perusahaan. Ketika perusahaan menerima opini audit going concern dimungkinkan juga akan mempengaruhi kinerja perusahaan, sebagaimana dijelaskan oleh PSA No. 30 SA Seksi 341 bahwa opini going concern merupakan opini auditor dimana seorang auditor ingin memastikan perusahaan yang diaudit dapat mempertahankan kelangsungan hidupnya. Sehingga auditor switching dapat menjadi cara dalam mengembalikan opini yang diinginkan perusahaan.

Pernyataan tersebut didukung oleh penelitian yang dilakukan oleh Astuti dan Ramantha (2014) bahwa opini going concern berpengaruh terhadap auditor switching. Berbeda dengan hasil penelitian Sinarwati (2010) bahwa opini going concern bukanlah opini yang buruk sehingga tidak memiliki pengaruh dalam auditor switching. Dalam penelitian Sinarwati (2010) justru membuktikan bahwa adanya pergantian manajemenlah yang mempengaruhi terjadinya auditor switching.

Suparlan dan Andayani (2010) tidak mendukung penelitian Sinarwati (2010) bahwa pergantian manajemen tidak berpengaruh terhadap auditor switching. Namun jika melihat kembali Undang-Undang Nomor 40 Tahun 2007 pasal 5 tentang Perseroan Terbatas menyatakan bahwa Dewan Direksi adalah organ perseroan yang berwenang dan bertanggungjawab penuh atas pengurusan Perseroan untuk kepentingan Perseroan. Ketika manajemen lama diganti maka seluruh atau sebagian kebijakan perusahaan akan diganti pula termasuk dalam hal pergantian auditor atau KAP.

Faktor- faktor yang mempengaruhi auditor switching sebagian besar dilihat dari sisi auditornya, namun pergantian auditor sebenarnya dapat dilihat dari sisi internal perusahaannya. Ekspansi internal merupakan perluasan perusahaan dengan memperbaiki aktivitas pendanaan. (Andriyanto, 2011). Suparlan dan Andayani (2010) menemukan bahwa ROE (Return On Equity) yang merupakan proksi dalam mengukur ekspansi internal tidak berpengaruh signifikan terhadap auditor switching, namun Kartika (2006) membuktikan bahwa dengan meningkatnya ROA perusahaan maka akan mempengaruhi pergantian KAP.

Sebagaimana alasan-alasan yang diuraikan di atas, serta adanya ketidakkonsistenan dari hasil penelitian terdahulu membuat Peneliti tertarik untuk melakukan penelitian terkait pergantian auditor dengan judul "PENGARUH OPINI 
GOING CONCERN, PERGANTIAN MANAJEMEN DAN EKSPANSI INTERNAL TERHADAP AUDITOR SWITCHING SECARA VOLUNTARY.

Tujuan penelitian ini adalah yang pertama Menguji opini going concern pengaruh terhadap auditor switching secara voluntary. Yang kedua Menguji pengaruh pergantian manajemen terhadap auditor switching secara voluntar. Yang ketiga Menguji pengaruh ekspansi internal terhadap auditor switching secara voluntar. Yang keempat Menguji secara bersama- sama pengaruh opini going concern, pergantian manajemen dan ekspansi internal terhadap auditor switching secara voluntary.

Berdasarkan uraian tersebut dapat dirumuskan hipotesis sebagai berikut:

$\mathrm{H}_{1}$ : Opini going concern berpengaruh terhadap auditor switching secara voluntary.

$\mathrm{H}_{2:} \quad$ Pergantian manajemen berpengaruh terhadap auditor switching secara voluntary.

$\mathrm{H}_{3 \mathrm{a}}$ : Tingkat pertumbuhan ROA (Return On Assets) berpengaruh terhadap auditor switching secara voluntary.

$\mathrm{H}_{3 \mathrm{~b}}$ : Tingkat pertumbuhan EPS (Earning Per Share) berpengaruh terhadap auditor switching secara voluntary.

$\mathrm{H}_{3 c}$ : Tingkat pertumbuhan penjualan berpengaruh terhadap auditor switching secara voluntary.

\section{METODE PENELITIAN}

Objek penelitian pada penelitian ini adalah mengenai pergantian kantor akuntan publik (auditor switching) pada perusahaan manufaktur. Populasi dalam penelitian ini adalah perusahaan yang terdaftar di Bursa Efek Indonesia (BEI) pada tahun 2010-2013. Teknik pengambilan sampel menggunakan metode purposive sampling untuk sampel bersyarat dengan kriteria dan pertimbangan. Jenis data yang digunakan dalam penelitian ini adalah data sekunder, data sekunder ini terdaftar di Bursa Efek Indonesia (www.idx.co.id) dan termuat dari web pros ${ }^{-}$ pektus pada tahun 2010-2013. Teknik pengumpulan data yang digunakan adalah studi dokumentasi, yaitu dengan menganalisis dan mengkaji data sekunder berupa laporan keuangan auditan dan laporan auditor perusahaan manufaktur yang dipublikasikan oleh Bursa Efek Indonesia. Teknik analisis data dalam penelitian ini menggunakan statistik deskriptif, dan uji hipotesis meliputi uji kelayakan model regresi, uji keseluruhan model, menguji koefisien determinasi, menguji multikolinearitas, matriks klasifikasi tabel, menguji omnibus test dan menguji koefisien regresi dan interpretasi.

\section{HASIL DAN PEMBAHASAN}

Statistik Deskriptif

\begin{tabular}{lccccc}
\hline & N & Minimum & Maximum & Mean & Std. Deviation \\
\hline AS (Y) & 288 & 0 & 1 &, 13 &, 331 \\
GC (X!) & 288 & 0 & 1 &, 16 &, 367 \\
PM (X2) & 288 & 0 & 1 &, 28 &, 452 \\
ROA (X3) & 288 & $-92,35$ & 956,29 & 2,2572 & 57,03656 \\
EPS (X5) & 288 & $-77,49$ & 15,81 &,- 7445 & 7,41978 \\
RAPID (Xa) & 288 &,- 58 & 2,94 &, 1724 &, 31972 \\
Valid N (listwise) & 288 & & & & \\
\hline
\end{tabular}

Sumber: Output SPSS 18.0
Tabel 4.1

Statistik Deskriptif 
Pengaruh Opini Going Concern...

558

Tabel 4.2 Hosmer and Lemeshow's Test
Berdasarkan tabel 4.1 diatas menunjukkan statistik deskriptif variabel $a^{-}$ ditor switching, opini going concern, tingkat pertumbuhan return on asset, earning per share, dan penjualan. Hasil tersebut menunjukkan variabel auditor switching $(\mathrm{Y})$, going concern $\left(\mathrm{X}_{1}\right)$, dan pergantian majemen $\left(\mathrm{X}_{2}\right)$ memiliki nilai minimum dan nilai maksimum masing-masing sebesar 0 dan 1 . Rata-rata yang dihasilkan adalah sebesar 0,13 untuk auditor switching (Y), 0,16 untuk opini going concern $\left(\mathrm{X}_{1}\right)$, dan 0,28 untuk variabel pergantian manajemen $\left(\mathrm{X}_{2}\right)$. Sedangkan standar deviasinya masing masing sebesar 0,331 (Y), 0,367 (X), dan 0,452 (X2).

Tabel deskriptif statistik menunjukkan tingkat pertumbuhan return on asset (ROA) memiliki nilai minimum sebesar -92,35 dengan nilai maksimum sebesar 956,29. Nilai rata-rata tingkat pertumbuhan ROA sebesar 2,2572 dengan standar deviasi sebesar 57,03656. Variabel pertumbuhan earning per share memiliki nilai minimum sebesar -77,49 dengan nilai maksimum sebesar 15,81 . Nilai rata-rata pertumbuhan earning per share sebesar -0,7445 dengan standar deviasi sebesar 7,41978 .

Tingkat pertumbuhan penjualan memiliki nilai minimum dan maksimum masing-masing sebesar -0,58 dan 2,94. Nilai rata-rata pertumbuhan penjualan memiliki nilai positif yaitu sebesar 0,1724 dan standar deviasi sebesar 0,31972.

Uji Kelayakan Model Regresi

\begin{tabular}{cccc}
\hline Step & Chi-square & df & Sig. \\
\hline 1 & 3,473 & 8 &, 901 \\
\hline
\end{tabular}

Hasil kelayakan model pada tabel 4.5 menunjukkan bahwa nilai Goodness of Fit Test Statistics adalah 0,901 atau lebih besar dari 0,05 berarti model dapat diterima karena cocok dengan data observasinya.

Uji Keseluruhan Model

$\underline{\text { Iteration History }}^{\text {abc }^{2}}$

\begin{tabular}{ccc}
\hline Iteration & -2 Log likelihood & Coefficients \\
\hline & & Constant \\
\hline Step 01 & 224,014 & $-1,500$ \\
2 & 217,138 & $-1,885$ \\
3 & 217,020 & $-1,945$ \\
4 & 217,020 & $-1,946$ \\
5 & 217,020 & $-1,946$ \\
\hline
\end{tabular}

\begin{tabular}{crrrrrrr}
\hline \multirow{2}{*}{ Iteration } & \multirow{2}{*}{$\begin{array}{c}\text { 2 Log } \\
\text { likelihood }\end{array}$} & Constant & \multicolumn{1}{c}{ GC } & PM & ROA & EPS & RAPID \\
\cline { 3 - 8 } Step 1 1 & 210,303 & $-1,778$ &, 854 &, 144 &, 000 &, 007 &, 621 \\
2 & 198,581 & $-2,407$ & 1,346 &, 264 &,- 001 &, 016 &, 908 \\
3 & 197,955 & $-2,587$ & 1,497 &, 316 &,- 002 &, 023 & 1,003 \\
4 & 197,927 & $-2,600$ & 1,509 &, 321 &,- 003 &, 025 & 1,012 \\
5 & 197,915 & $-2,601$ & 1,509 &, 321 &,- 005 &, 027 & 1,012 \\
6 & 197,905 & $-2,601$ & 1,510 &, 320 &,- 007 &, 030 & 1,012 \\
7 & 197,878 & $-2,605$ & 1,513 &, 318 &,- 018 &, 042 & 1,013 \\
8 & 197,867 & $-2,609$ & 1,516 &, 316 &,- 031 &, 055 & 1,015 \\
9 & 197,867 & $-2,609$ & 1,516 &, 316 &,- 031 &, 055 & 1,015 \\
\hline
\end{tabular}

Tabel 4.3 Perbandingan Nilai 2Log L Awal Dengan Nilai -2Log L Akhir 
Tabel di atas menunjukkan bahwa nilai -2 $\log L$ mengalami penurunan. Nilai -2 Log $L$ pada beginning block (step) $O$ sebesar mengalami penurunan menjadi pada block (step) 1. Ghozali (2011) menyatakan bahwa nilai -2 LogL yang mengalami penurunan menandakan bahwa model statistik tersebut semakin fit dengan data.

Uji Koefisien Determinasi

Model Summary

\begin{tabular}{cccc}
\hline Step & -2 Log likelihood & Cox \& Snell R Square & Nagelkerke R Square \\
\hline 1 & $197,867^{\mathrm{a}}$ &, 064 &, 122 \\
\hline
\end{tabular}

Cox-Snell dan Nagelkerke $R$ memiliki analogi yang sama dengan nilai $R$ Square pada regresi linier. Berdasarkan tabel di atas diketahui bahwa nilai Nagelkerke $R$ Square sebesar 0,122. Hal ini menunjukkan bahwa $12,2 \%$ variabel dependen yaitu auditor switching dijelaskan oleh perubahan opini going concern, pergantian manajemen, ekspansi internal (tingkat pertumbuhan return on asset, earning per share dan penjualan) sebagai variabel independennya. Sisanya sebesar $87,8 \%$ dijelaskan oleh variabel lain di luar model penelitian ini.

Uji Multikolienaritas

\begin{tabular}{crrrrrr}
\hline & Constant & \multicolumn{1}{l}{ GC } & \multicolumn{1}{c}{ PM } & \multicolumn{1}{c}{ ROA } & \multicolumn{1}{c}{ EPS } & RAPID \\
\hline Step 1 Constant & 1,000 &,- 467 &,- 442 &, 135 &,- 137 &,- 426 \\
GC &,- 467 & 1,000 &,- 043 &,- 080 &, 103 &, 092 \\
PM &,- 442 &,- 043 & 1,000 &, 055 &,- 043 &, 029 \\
ROA &, 135 &,- 080 &, 055 & 1,000 &,- 969 &,- 030 \\
EPS &,- 137 &, 103 &,- 043 &,- 969 & 1,000 &, 025 \\
RAPID &,- 426 &, 092 &, 029 &,- 030 &, 025 & 1,000 \\
\hline
\end{tabular}

Sumber: Output SPSS 18.0

Berdasarkan tabel 4.7 di atas, matrik korelasi menunjukkan tidak adanya gejala multikolinearitas yang serius antar variabel independen, sebagaimana terlihat nilai koefisien korelasi antar variabel bebas masih jauh di bawah 0,90 (Ghozali, 2011). Korelasi terendah variabel independen terjadi antara variabel return on asset (ROA) dan variabel earning per share (EPS) yaitu sebesar -0,969. Korelasi tertinggi terjadi antara variabel opini going concern (GC) dengan variabel earning per share (EPS) yaitu sebesar 0,103 dan masih berada sangat jauh di bawah 0,90 .

Matrik Klasifikasi

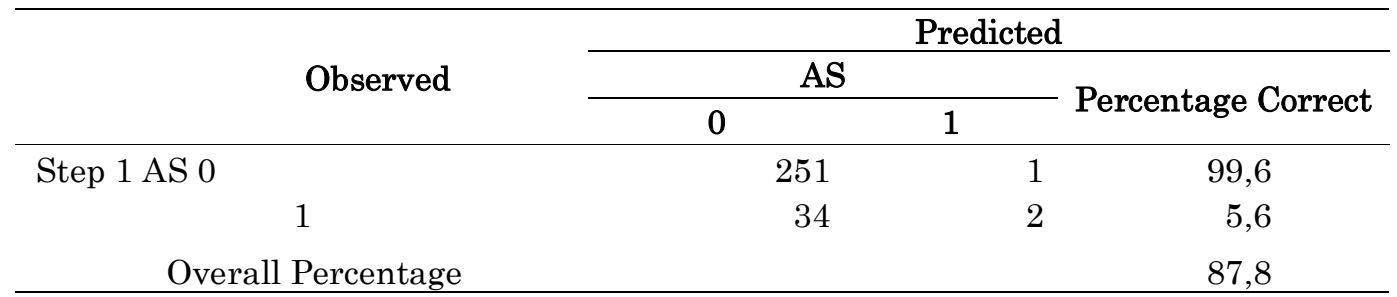

a. The cut value is, 500

Sumber: Output SPSS 18.0

Tabel menunjukkan kekuatan prediksi dari model regresi untuk memprediksi kemungkinan perusahaan melakukan auditor switching adalah 5,6\%. Hal ini menunjukkan bahwa dengan menggunakan model regresi yang digunakan, terdapat sebanyak 2 perusahaan $(5,6 \%)$ yang diprediksi akan melakukan auditor
JRAK

Tabel 4.4

Uji Nagelkerke R

Square

Tabel 4.5

Matrik Korelasi

Antar Variabel

Independen

Correlation Matrix

Tabel 4.6

Classification Table ${ }^{\mathrm{a}}$ 
Pengaruh Opini Going Concern...

560

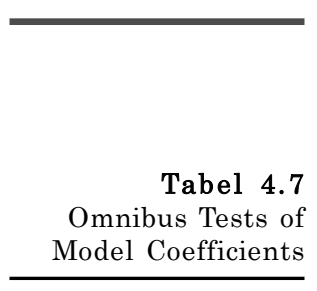

Tabel 4.8 Variables in the Equation switching dari 36 perusahaan yang melakukan auditor switching. Kekuatan prediksi model perusahaan yang tidak melakukan auditor switching adalah sebesar 99,6\% yang berarti bahwa dengan model regresi yang digunakan ada sebanyak 251 perusahaan $(99,6 \%)$ yang diprediksi tidak melakukan auditor switching dari total 252 perusahaan yang tidak melakukan auditor switching.

Omnibus Test

\begin{tabular}{llclc}
\hline & & Chi-square & df & Sig. \\
\hline \multirow{2}{*}{ Step 1 } & Step & 19,152 & 5 &, 002 \\
& Block & 19,152 & 5 &, 002 \\
& Model & 19,152 & 5 &, 002 \\
\hline
\end{tabular}

Sumber: Output SPSS 18.0

Hasil omnibus test diperoleh dari koefisien chi-square sebesar 19,152 dengan tingkat signifikansi sebesar 0,002. Pengujian memberikan hasil yang signifikan sehingga dapat disimpulkan bahwa variabel opini going concern, pergantian manajemen, ekspansi internal (tingkat pertumbuhan return on asset, earning per share, dan penjualan) secara bersama-sama (simultan) berpengaruh terhadap auditor switching.

Koefisien Regresi

\begin{tabular}{crrrrrrr}
\hline & \multicolumn{1}{c}{ B } & \multicolumn{1}{c}{ S.E. } & Wald & df & \multicolumn{1}{c}{ Sig. } & Exp(B) \\
\hline Step l la GC $^{\text {G }}$ & 1,516 &, 406 & 13,944 & & 1 &, 000 & 4,554 \\
& PM &, 316 &, 397 &, 634 & 1 &, 426 & 1,372 \\
ROA & 0 & 0 &, 119 &, 067 & 1 &, 796 &, 970 \\
EPS &, 055 &, 132 &, 172 & 1 &, 678 & 1,056 \\
RAPID & 1,015 &, 491 & 4,277 & 1 &, 039 & 2,759 \\
Constant & $-2,609$ &, 288 & 81,798 & 1 &, 000 &, 074 \\
\hline
\end{tabular}

Sumber: Output SPSS 18.0

Hasil pengujian model regresi logistik dengan variabel dependen auditor switching diperoleh persamaan berikut ini.

SWITCH

LU I SWITCH $=22,609+1,516 \mathrm{GC}+0,316 \mathrm{PM} \sim 0,31 \mathrm{R} 0 \mathrm{~A}+0,55 \mathrm{EPS}+1,015 \mathrm{RAPID}$

Hasil pengujian variabel opini going concern $\left(\mathrm{X}_{1}\right)$ menunjukkan bahwa koefisien regresi positif sebesar 1,516 dengan tingkat signifikansi sebesar 0,000, lebih kecil dari a sebesar 0,05. Karena tingkat signifikansi lebih kecil dari 0,05 maka dapat disimpulkan bahwa variabel independen (GC) memiliki pengaruh terhadap auditor switching.

Hasil pengujian variabel pergantian manejemen $\left(\mathrm{X}_{2}\right)$ menunjukkan bahwa koefisien regresi positif sebesar 0,316 dengan tingkat signifikansi sebesar 0,426, lebih besar dari a sebesar 0,05. Karena signifikansi lebih besar dari pada a maka hipotesis ke-2 ditolak dengan kesimpulan bahwa pergantian manajemen (PM) tidak memiliki pengaruh terhadap auditor switching.

Hasil pengujian variabel pertumbuhan return on assets $(\mathrm{ROA})$ sebagai $\mathrm{X}_{3}$ menunjukkan bahwa koefisien regresi negatif sebesar -0,031 dengan tingkat signifikansi sebesar 0,796, lebih besar dari a =0,05. Maka hipotesis ke-3 ditolak. Pada model regresi logistik menunjukkan bahwa koefisiennya negatif, yang menyimpulkan bahwa memiliki hubungan yang berlawanan arah yaitu ketika pertumbuhan ROA semakin kecil maka perusahaan akan cenderung melakukan auditor switching. 
Hasil pengujian variabel pertumbuhan earning per share (EPS) sebagai $\mathrm{X}_{4}$ menunjukkan bahwa koefisien regresi bernilai positif sebesar 0,055 dengan tingkat signifikansi sebesar 0,678 , lebih besar dari a $=0,05$. Karena tingkat signifikansi lebih besar maka variabel pertumbuhan earning per share tidak berpengaruh terhadap auditor switching.

Hasil pengujian variabel pertumbuhan penjualan (RAPID) sebagai $\mathrm{X}_{5}$ menunjukkan bahwa koefisien regresi bernilai positif sebesar 1,015 dengan tingkat signifikansi sebesar 0,039, lebih kecil dari a $=0,05$. Karena tingkat signifikansi lebih kecil maka hipotesis dapat diterima, sehingga dapat disimpulkan bahwa pertumbuhan penjualan berpengaruh terhadap auditor switching.

\section{Pembahasan}

Hipotesis 1 (Hi) bertujuan untuk menguji pengaruh opini going concern terhadap auditor switching. Pengujian memberikan hasil yang signifikan, dimana hipotesis 1 diterima yaitu opini going concern berpengaruh terhadap auditor switching. Penelitian ini didukung oleh Astuti dan Ramantha (2014) yang menyatakan bahwa opini audit going concern memiliki pengaruh terhadap auditor switching, namun hasil penelitian ini tidak mendukung hasil penelitian Sinarwati (2010).

Hipotesis $2\left(\mathrm{H}_{2}\right)$ bertujuan untuk menguji pengaruh pergantian manajemen terhadap auditor switching. Pengujian memberikan hasil yang tidak signifikan sehingga dapat disimpulkan bahwa pergantian manajemen tidak berpengaruh terhadap auditor switching. Hasil penelitian ini didukung oleh Sinarwati (2010) dan Dwi (2010), dimana perusahaan memutuskan untuk tidak mengganti auditornya setelah adanya perubahan manajemen.

Hipotesis 3a bertujuan untuk menguji pengaruh tingkat pertumbuhan ROA (Return On Assets) terhadap auditor switching. Pengujian memberikan hasil yang tidak signifikan, sehingga dapat disimpulkan bahwa tingkat pertumbuhan ROA tidak berpengaruh terhadap auditor switching, yang berarti tidak berhasil mendukung hipotesis 3a. Hasil penelitian ini mendukung penelitian Dwi (2010), Wijayani dan Januarti (2011).

Hipotesis $3 \mathrm{~b}$ bertujuan untuk menguji pengaruh tingkat pertumbuhan EPS (Earning Per Share) terhadap auditor switching. Pengujian memberikan hasil yang tidak signifikan sehingga dapat disimpulkan bahwa tingkat pertumbuhan EPS (Earning Per Share) tidak berpengaruh terhadap auditor switching. Hasil penelitian ini mendukung Dwi (2010) bahwa tingkat pertumbuhan EPS yang tinggi hanya akan mempengaruhi tingkat keuntungan bagi pemegang saham.

Hipotesis $3 c$ bertujuan untuk menguji pengaruh tingkat pertumbuhan penjualan terhadap auditor switching. Pengujian memberikan hasil yang signifikan sehingga dapat disimpulkan bahwa tingkat pertumbuhan penjualan berpengaruh terhadap auditor switching atau hipotesis 3c diterima. Penelitian ini tidak mendukung hasil penelitian Dwi (2010).

\section{KESIMPULAN}

Penelitian ini dapat disimpukan bahwa secara parsial (uji statistik T) variabel pergantian manajemen, tingkat pertumbuhan ROA dan EPS tidak berpengaruh terhadap auditor switching, sedangkan untuk variabel opini going concern dan tingkat pertumbuhan penjualan berpengaruh terhadap auditor switching pada perusahaan manufaktur yang terdaftar di BEI pada tahun tersebut. Selain itu, hasil uji F menjelaskan bahwa secara bersama-sama variabel opini going concern, pergantian manajemen, dan ekspansi internal dengan proksi tingkat pertumbuhan ROA (Return On Assets), EPS (Earning Per Share), penjualan berpengaruh terhadap auditor switching. Dari kelima variabel tersebut, variabel yang sangat berpengaruh terhadap auditor switching pada perusahaan manufaktur yaitu variabel opini going concern dan tingkat pertumbuhan penjualan. 
Pengaruh Opini Going Concern...

562
Keterbatasan penelitian yaitu pertama peneliti hanya berfokus pada perusahaan manufaktur, yang kedua pengukuran variabel hanya berdasar pada dewan komisaris saja, yang ketiga ekspansi internal bisa diproksikan dengan melakukan merge dan akuisisi. Saran untuk penelitian selanjutnya sebaiknya menggunakan sampel yang berbeda tidak hanya pada manufaktur, sebaiknya menambahkan variabel yang mempengaruhi auditor switching.

\section{DAFTAR PUSTAKA}

Andriyanto, Sandra Aristiani. 2011. Analisis Merger dan Kinerja Keuangan PT. Kalbe Farma, Tbk. Skripsi Fakultas Ekonomi Universitas Diponegoro, Semarang.

Astrini, Novia Retno dan Dul Muid. 2013. "Analisis Faktor-Faktor Yang Mempengaruhi Perusahaan Melakukan Auditor Switching Secara Voluntary". Diponegoro Journal Of Accounting, Vol. 2 No. 3 pp: 1-11, ISSN \{Online)2337-3806.

Astuti, Ni Luh P.P dan I Wayan Ramantha. 2014. "Pengaruh Audit Fee, Opini Going Concern, Financial Distress dan Ukuran Perusahaan Pada Pergantian Auditor". E-Jurnal Akuntansi Universitas Udayana 7.3:663-676, ISSN: 23028556

Dwi, Bondan. 2010. Pengaruh Client Contracting Environment, Reputasi Klien, dan Ukuran KAP terhadap Pergantian KAP pada Perusahaan Manufaktur yang terdaftar di BEI. Skripsi Fakultas Ekonomi Universitas Sebelas Maret, Surakarta.

Dewi, Sri Ika Candra. 2009. Pengujian Reaksi Pasar Akibat Publikasi Merger Dan Akuisisi. Thesis Fakultas Ekonomi Universitas Atma Jaya, Yogjakarta.

Ghozali, Imam. 2011. Aplikasi Analisis Multivariate dengan Program IBM SPSS 19. Semarang: Badan Penerbit Universitas Diponegoro.

Halim, Abdul. 2001. Auditing 1 (Dasar-Dasar Audit Laporan Keuangan). Edisi ke2. Yogyakarta: AMP YKPN.

Kartika, R.D. 2006. Analisis Faktor Yang Mempengaruhi Keputusan Klien Melakukan Pergantian Kantor Akuntan Publik (Auditor Changes). Skripsi Fakultas Ekonomi Universitas Brawijaya, Malang.

Rahmawati, Filka. 2011. Faktor-Faktor Yang Mempengaruhi Perusahaan Yang Terdaftar di BEI Melakukan Pergantian Kantpr Akuntan Publik. Skripsi Fakultas Ekonomi Universitas Diponegoro, Semarang.

Sinarwati, Ni Kadek. 2010. "Mengapa Perusahaan Manufaktur Yang Terdaftar di BEI Melakukan Pergantian Kantor Akuntan Publik?”. Simposium Nasional Akuntansi XIII Purwokerto.

Sugiyono. 2002. Metode Penelitian Bisnis. Bandung: CV. Alfabeta.

Suparlan dan Wuryan Andayani. 2010. "Analisis Empiris Pergantian Kantor Akuntan Publik Setelah Ada Kewajiban Rotasi Audit". Simposium Nasional Akuntansi XIII Purwokerto. 